\title{
Effect of the caries-protective self-assembling peptide P11-4 on shear bond strength of metal brackets
}

\author{
Thomas Knaup $^{1} \cdot$ Heike Korbmacher-Steiner ${ }^{1} \cdot$ Anahita Jablonski-Momeni $^{1}$ (iD \\ Received: 28 January 2020 / Accepted: 21 June 2020 / Published online: 2 September 2020 \\ (c) The Author(s) 2020, corrected publication 2021
}

\begin{abstract}
Purpose During orthodontic treatment with fixed appliances, demineralization around brackets often occurs. The aim of this in vitro study was to investigate the effect of the caries-protective self-assembling peptide P11-4 (SAP P11-4) on the shear bond strength of metal brackets.

Methods In all, 45 extracted human wisdom teeth were available for the study. The teeth were randomly divided into 3 groups (each $n=15$ ) and pretreated as follows: test group 1: application of SAP P11-4 (Curodont Repair, Windisch, Switzerland) and storage for $24 \mathrm{~h}$ in artificial saliva; test group 2: application of SAP P11-4; control group: no pretreatment with SAP P11-4. A conventional metal maxillary incisor bracket (Discovery, Dentaurum, Ispringen) was adhesively bonded to each buccal surface. The shear bond strength was tested according to DIN 13990. After shearing, the Adhesive Remnant Index (ARI) was determined microscopically (10x magnification). Analysis of variance (ANOVA) was used to check the groups for significant differences $(\alpha=0.05)$. The distribution of the ARI scores was determined with the $\chi^{2}$ test.

Results There was no significant difference in shear forces between the groups $(p=0.121)$ : test group $1=17.0 \pm 4.51 \mathrm{MPa}$, test group $2=14.01 \pm 2.51 \mathrm{MPa}$, control group $15.54 \pm 4.34 \mathrm{MPa}$. The distribution of the ARI scores between the groups did not vary ( $p$-values $=0.052-0.819)$.

Conclusion The application of the caries protective SAP P11-4 before bonding of brackets did not affect the shear bond strength. Therefore, pretreatment of the enamel surface with SAP P11-4 shortly before bracket insertion can be considered.

Keywords Oral hygiene $\cdot$ Orthodontic appliances, fixed $\cdot$ Dental white spots $\cdot$ Dental enamel $\cdot$ Dental caries, prevention

\section{Der Einfluss des kariesprotektiven Peptids P11-4 auf den Haftverbund zwischen Metallbracket und Zahnschmelz}

\section{Zusammenfassung}

Ziel Während einer kieferorthopädischen Behandlung mit festsitzenden Apparaturen können in der Bracketzirkumferenz Demineralisationen entstehen. Im Rahmen dieser In-vitro-Studie sollte der Einfluss des kariesprotektiven Peptids P11-4 auf das Haftverhalten zwischen Metallbrackets und Zahnoberfläche untersucht werden.

Prof. (apl.) Dr. med. dent. Anahita Jablonski-Momeni momeni@staff.uni-marburg.de

1 Dental School, Dept. of Orthodontics, Philipps-University Marburg, Georg-Voigt Str. 3, 35039 Marburg, Germany 
Methoden Fünfundvierzig extrahierte humane Weisheitszähne standen für die Studie zur Verfügung. Die Zähne wurden randomisiert auf 3 Gruppen verteilt (je $n=15$ ) und unterschiedlich vorbehandelt: Testgruppe 1: Applikation von P11-4 (Curodont Repair, Windisch, Schweiz) und Lagerung für 24h in künstlichem Speichel; Testgruppe 2: Applikation von P11-4; C = Kontrollgruppe: keine Vorbehandlung. Auf jede Bukkalfläche wurde ein konventionelles, metallisches Twinbracket (Discovery, Dentaurum, Ispringen) adhäsiv befestigt. Die Scherhaftfestigkeit wurde nach DIN 13990 mit einer Universalprüfmaschine untersucht. Nach dem Abscheren wurde der ARI (Adhesive Remnant Index) mikroskopisch bestimmt (Vergr. 10:1). Mittels ANOVA (Analysis of Variance) wurden die Gruppen auf signifikante Unterschiede überprüft $(\alpha=0,05)$. Die Verteilung der ARI-Scores wurde mit dem $\chi^{2}$-Test ermittelt.

Ergebnisse Es bestand kein statistisch signifikanter Unterschied in Bezug auf den Haftverbund zwischen den Untersuchungsgruppen ( $p=0,121)$ : Testgruppe 1 = 17,0 MPa (Standardabweichung [SD] 4,51), Testgruppe 2=14,01 MPa (SD 2,51), Kontrollgruppe 15,54 MPa (SD 4,34). Die Verteilung der ARI-Scores zwischen den Gruppen war statistisch nicht signifikant unterschiedlich ( $p$-Werte 0,052-0,819).

Schlussfolgerung Die Anwendung des kariesprotektiven Peptids P11-4 vor der regulären Schmelzätztechnik zeigte weder sofort nach der Applikation noch nach 24h Lagerung in künstlichem Speichel einen signifikanten Einfluss auf den Haftverbund von Brackets. Somit kann eine Vorbehandlung der Schmelzoberfläche mit P11-4 unmittelbar vor Bracketinsertion in Betracht gezogen werden.

Schlüsselwörter Mundhygiene · Festsitzende kieferorthopädische Apparaturen · Dentale White Spots · Zahnschmelz . Kariesprävention

\section{Introduction}

Dental caries is a biofilm-mediated, multifactorial, noncommunicable disease resulting in net mineral loss of dental hard tissues and is determined by biological, behavioral, psychosocial, and environmental factors [30, 42]. Orthodontic treatments, especially with fixed appliances, provide a hurdle to oral hygiene and lead to patients becoming high-risk caries patients. During an orthodontic treatment, plaque that accumulates around the brackets is not removed to the same level as would be required, resulting in demineralization. Consequently initial lesions form around the brackets [38].

The demineralization of the enamel leads to an altered light refraction, which causes a whitish, opaque surface and can have an impact on the esthetic outcome of the orthodontic treatment. It is reported that white spot lesions have a limited ability to improve after appliance removal and can be detectable many years after treatment [46]. The incidence of new carious lesions that formed during orthodontic treatment was found to be $45.8 \%$ [47] and development of cavitations after treatment with multibracket appliances was reported in $26.9 \%$ of patients [17]. It is even stated that the high treatment demand and occurrence of biofilm-related complications make orthodontic treatment a potential public health threat [44].

Therefore, the emphasis in the prevention of caries during orthodontic treatment should be on management strategies which focus on the remineralization of the lesions, e.g., the use of topical fluoride $[13,20,21]$ and amorphous calcium phosphate [35]. Moreover, oral hygiene instructions and regular professional cleanings with motivation of pa- tients have been recommended to inhibit demineralization [32]. The use of reminder systems to improve oral hygiene and adherence to appointments can reduce prevalence of white spot lesions [33].

The use of enamel sealant is another common approach for the prevention of initial lesions. These are used to apply a protective layer to the smooth surfaces and fissures. Various mechanisms of action are known: remineralization of tooth enamel [28], prevention of the formation of a biofilm $[11,22]$, and the formation of a barrier between enamel and the dental plaque [49]. The sealants may or may not contain fluorides [50] and are used before or after bracket application $[4,7,8,18,19,37]$. The use of such sealants appears to have a caries-preventive effect although the effectiveness seems to vary depending on the sealant used [12, 39, 48, $51]$.

Despite the efforts described in the literature, the formation of white spot lesions remains a clinical issue within orthodontic treatment and new ways should be sought to prevent caries. One such novel approach is the self-assembling peptide (SAP) technology, which was recently shown to promote the regeneration of enamel within the depth of the carious lesion [2, 10, 23, 25, 26] and inhibit demineralization in high caries risk clinical situations [24]. From the data recently published on SAP P11-4, it can be concluded that the application of SAP P11-4 makes the enamel surface more resistant towards caries and acid attack in general. Previous studies have shown SAP P11-4 to have a positive influence on the bonding of composite resins onto carious dentine if used in combination with an etch-andrinse system $[5,6]$. 
The present study aimed to investigate the influence of SAP P11-4 on shear bond strength of metal brackets to the enamel surface. The hypothesis was that there is no significant influence of SAP P11-4 on shear bond strength.

\section{Materials and methods}

\section{Sample preparation}

In all, 45 extracted human unerupted third molars were included in this in vitro study. The use of extracted teeth was approved by the Ethics Committee of the medical faculty of the Philipps-University Marburg (Ref. No. 107/12). Before the surgical removal of the teeth, each patient was informed and consent was obtained for the use of the teeth for study purposes. The surface of each tooth was examined under a stereomicroscope (Leica MS 5, Leitz, Wetzlar, Germany) at $16 \times$ magnification and samples with mineralization disorders or damage caused by the extraction procedure were not included. The teeth were stored in a $0.5 \%$ chloramine $\mathrm{T}$ solution directly after extraction and were cleaned after one week.

\section{Sample treatment and bracket placement}

The samples were stored in deionized water according to DIN ISO 3696 at $4{ }^{\circ} \mathrm{C}$. Teeth were embedded in a polytetrafluoroethylene (PTFE) ring using a colorless cold-curing plastic (Technovit 4004, Heraeus, Hanau, Germany), whereby the buccal enamel surface was aligned parallel to the planned shear direction. Teeth were randomly assigned to three groups ( $n=15$ in each group). In test group 1, SAP P11-4 (Curodont Repair, Windisch, Switzerland) was applied after cleaning and enamel conditioning according to the manufacturer's instruction. In detail, the enamel was wiped with sodium hypochlorite $(2 \%)$, and etched with $36 \%$ phosphoric acid (Gel etch, Ormco Pty. Ltd., Orange, CA, USA) for $20 \mathrm{~s}$. The enamel was rinsed and SAP P11-4 was applied via the supplied applicator sponge. SAP P11-4 was left for $5 \mathrm{~min}$ and the samples where then stored for $24 \mathrm{~h}$ in artificial saliva. After renewed enamel conditioning with $36 \%$ phosphoric acid, a conventional metal maxillary incisor bracket (Discovery, Dentaurum, Ispringen, Germany) was adhesively attached to each buccal surface (Transbond ${ }^{\mathrm{TM}} \mathrm{XT}$, 40 s light curing with Elipar ${ }^{\mathrm{TM}}$, both materials 3M Unitek, Seefeld, Germany). In test group 2, SAP P11-4 was applied as described for group 1 SAP P11-4 then a metal bracket was applied after $5 \mathrm{~min}$, followed by renewed enamel conditioning. In the control group, brackets were adhesively fixed after conditioning as previously described. All samples were stored in ultrapure water of quality 3 according to DIN ISO $3696\left(37 \pm 2^{\circ} \mathrm{C}\right)$ for $24 \mathrm{~h}$.

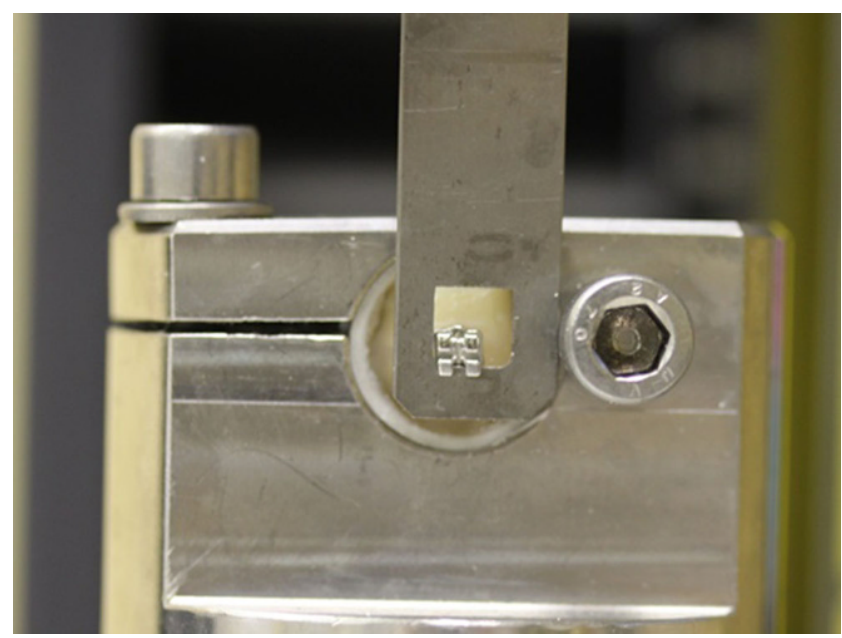

Fig. 1 Processing of a specimen. The load of the brackets was conducted with the help of the Zwick universal testing machine in occlusal-gingival direction

Abb. 1 Testung einer Probe. Die Belastung des Brackets erfolgte durch die Universalprüfmaschine Zwick in okklusal-gingivaler Richtung

\section{Debonding}

All specimens were tested using a standardized and computer-controlled hydraulic testing machine (Zwick 1120.5 ${ }^{\circledR}$, Zwick, Germany; Fig. 1) according to DIN 13990. Each specimen was positioned so that the bonding surface between bracket and enamel was aligned parallel to the occlusal-to-gingival shear force. Shear forces were measured by the force sensor of the testing machine during each test (traverse speed $1 \mathrm{~mm} / \mathrm{min}$ ) until the compound broke and were continuously recorded in a force-displacement diagram. To convert the forces into MPa values, the adhesive surface of the brackets of $13.12 \mathrm{~mm}$ (according to manufacturer's specifications) was used.

\section{Adhesive remnant index}

After removal of the brackets, the remaining residual adhesive material on each tooth surface was determined according to the Adhesive Remnant Index (ARI) [3, 34] by two examiners under $10 \times$ magnification in a light microscope (Leica Z6 APO, Leica Microsystems GmbH, Wetzlar Germany). The ARI was categorized as follows: score $0=$ no adhesive on the enamel surface; grade 1 and $2=$ less or more than $50 \%$ of the residual adhesive on the enamel surface; grade $3=$ entire adhesive on the enamel surface. If ARI assessment differed between assessors, a consensus decision was made. 


\section{Statistical evaluation}

The statistical evaluation was performed using MedCalc statistical software (v 17.4). Data were tested for normal distribution using the Shapiro-Wilk's test. The values were normally distributed $(p>0.05)$ and analysis of variance (ANOVA) was used to analyze the groups for significant differences. The distribution of the ARI scores was determined with the $\chi^{2}$ test. The significance level was set at $\alpha=0.05$ for all tests.

According to the DIN 13990 standard (DIN: Deutsche Institut für Normung), a minimum of 10 samples in each group was required to be included in the study. Preliminary unpublished data showed no significant differences between groups ( $n=13$ in each group) with a pooled standard deviation of $4.35 \mathrm{MPa}$ (95\% confidence interval [CI] of difference $-4.53 ; 2.51)$. Based on these calculations a num- ber of 15 samples were included in each group to increase the power.

\section{Results}

During the debonding tests, no bracket or enamel fractures were observed. Mean values for the sheer bond strength were as follows: test group 1: $17.00 \pm 4.51 \mathrm{MPa}$, test group 2: $14.01 \pm 2.51$, and control group: $15.54 \pm 4.34$. Test group 1 and 2 did not show significant differences from the control group $(p=0.121)$. The original hypothesis is not rejected. The corresponding boxplots are presented in Fig. 2.

Adhesive Remnant Index (ARI) values are displayed in Table 1 . For all groups the ARI scores were predominantly 1 and 2, with only one specimen in test group 2 having a score
Fig. 2 Boxplots of the shear bond strength (MPa) measured for the specimens in all groups. Test group 1: application of P11-4, 24h storage in artificial saliva, bracket insertion; test group 2: application of P11-4, bracket insertion; control group: no pretreatment with $\mathrm{P} 11-4$ prior to bracket insertion

Abb. 2 Boxplots der Scherhaftfestigkeit (MPa) für die Proben in allen Gruppen. Testgruppe 1: Auftragen von P11-4 und Lagerung für $24 \mathrm{~h}$ in künstlichem Speichel + Bracketapplikation; Testgruppe 2: Auftragen von P11-4+ Bracketapplikation; Kontrollgruppe: keine Vorbehandlung mit P11-4 vor Bracketapplikation

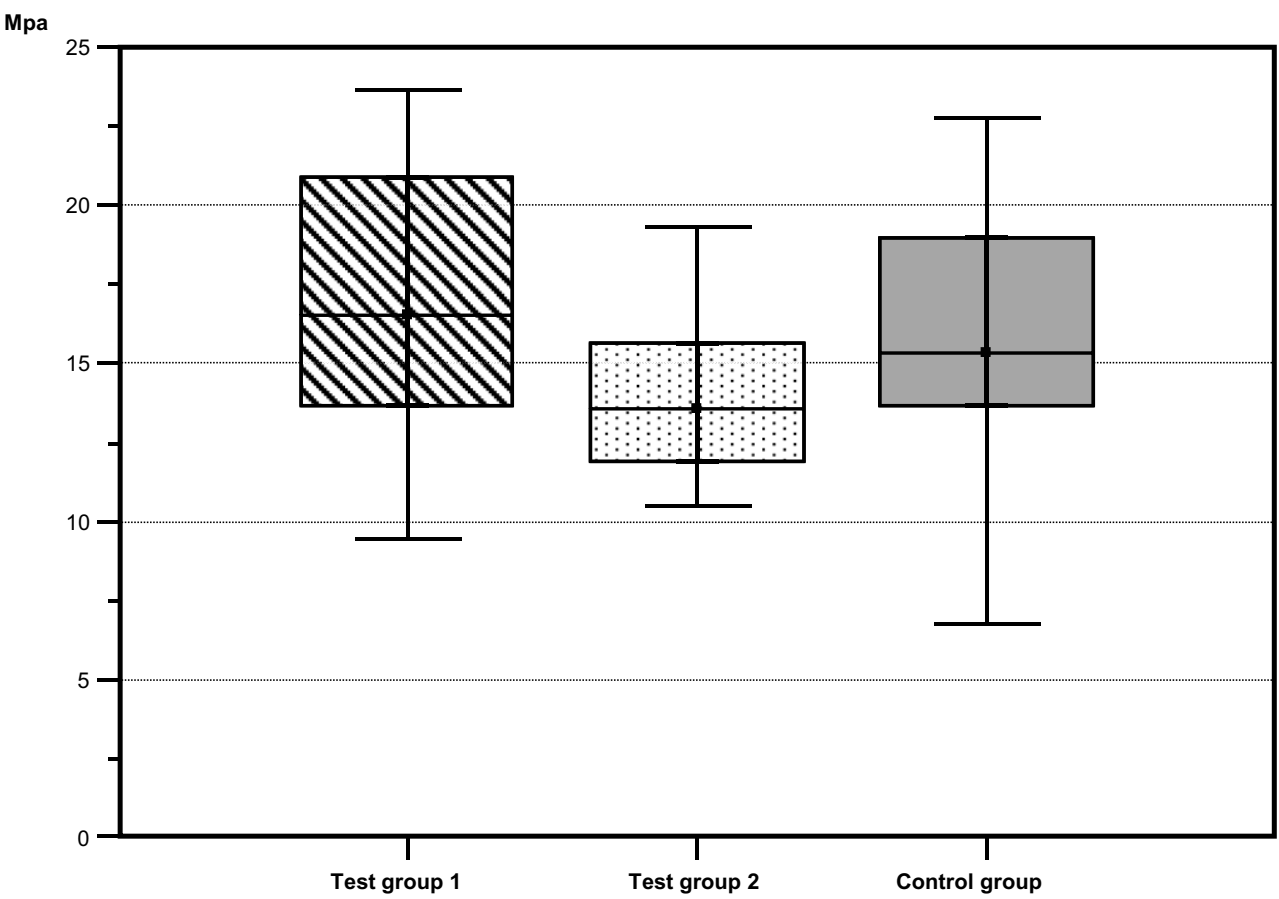

Table 1 Distribution of the Adhesive Remnant Index (ARI) scores in each group with $10 \times$ magnification

Tab. 1 Verteilung der ARI(Adhesive Remnant Index)-Scores in jeder Gruppe nach Betrachtung mit einer Vergrößerung von 10:1

\begin{tabular}{|c|c|c|c|}
\hline ARI score & $\begin{array}{l}\text { Test group 1: } \\
\mathrm{P} 11-4,24 \mathrm{~h} \text { storage in artificial } \\
\text { saliva, bracket insertion } \\
N(\%)\end{array}$ & $\begin{array}{l}\text { Test group 2: } \\
\text { P11-4, bracket } \\
\text { insertion } \\
N(\%)\end{array}$ & $\begin{array}{l}\text { Control group: } \\
\text { no pretreatment with P11-4 } \\
\text { prior to bracket insertion } \\
N(\%)\end{array}$ \\
\hline 0: no adhesive on the enamel surface & $0(0)$ & $1(6.7)$ & $0(0)$ \\
\hline $\begin{array}{l}\text { 1: less than } 50 \% \text { of the residual adhesive } \\
\text { on the enamel surface }\end{array}$ & $6(40)$ & $6(40)$ & $6(40)$ \\
\hline $\begin{array}{l}\text { 2: more than } 50 \% \text { of the residual adhesive } \\
\text { on the enamel surface }\end{array}$ & $8(53.3)$ & $6(40)$ & $6(40)$ \\
\hline 3: entire adhesive on the enamel surface & $1(6.7)$ & $2(13.3)$ & $3(20)$ \\
\hline$N(\%)$ total & $15(100)$ & $15(100)$ & $15(100)$ \\
\hline
\end{tabular}


Fig. 3 Representative surface images for each Adhesive Remnant Index (ARI) score: a ARI score 0 , b ARI score 1, c ARI score 2, d ARI score 3

Abb. 3 Repräsentative Aufnahmen für jeden ARI(Adhesive Remnant Index)-Score:

a ARI-Score 0 , b ARI-Score 1, c ARI-Score 2, d ARI-Score 3
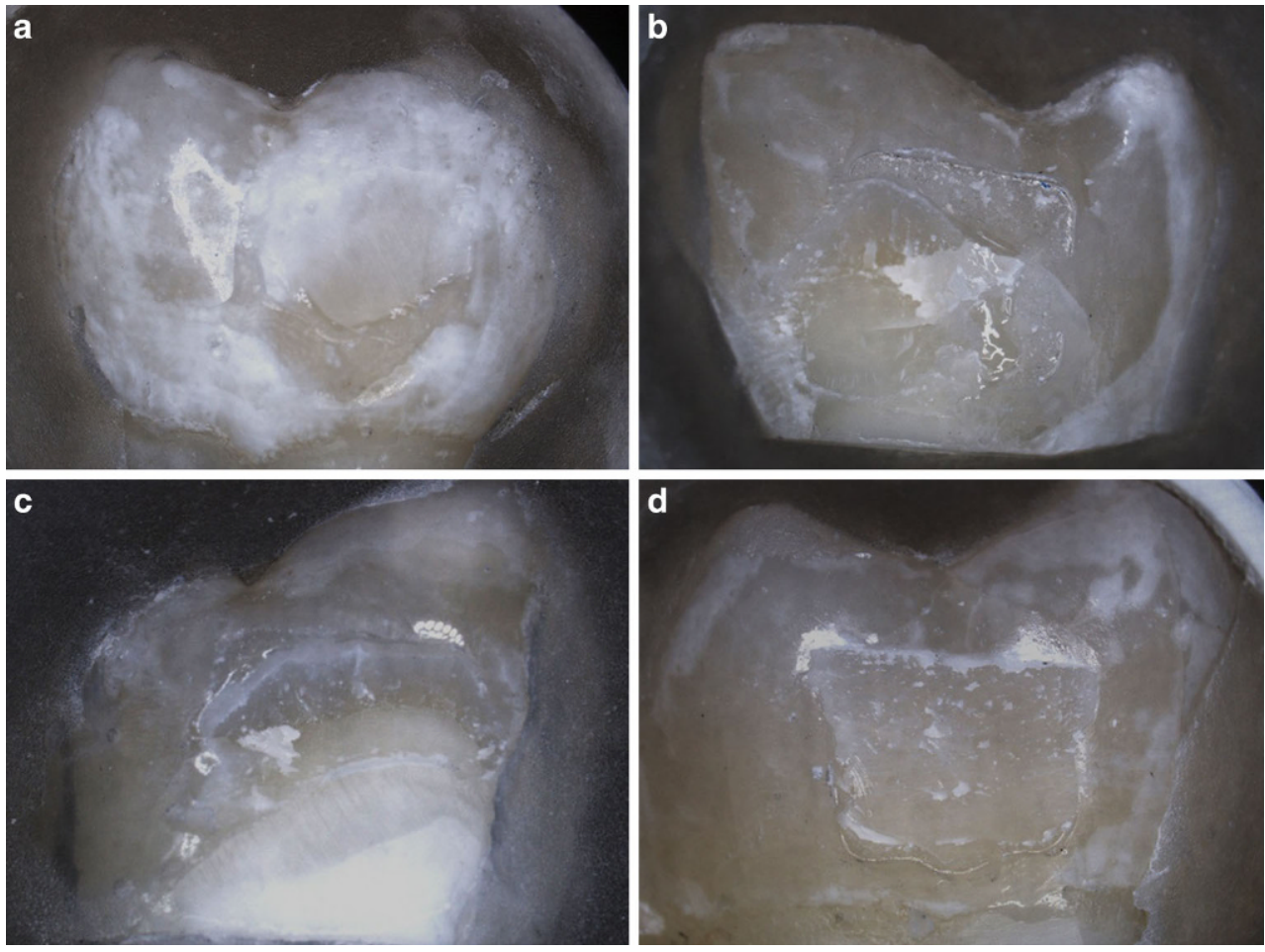

of 0 and all groups having a small number of ARI 3. Test group 1 and 2 and control group did not show significant differences between the distribution of the ARI scores: test group 1 vs. test group 2: $p=0.143$, test group 1 vs. control group: $p=0.052$ and test group 2 vs. control group: $p=0.819$. Representative surface images for each ARI score are presented in Fig. 3.

\section{Discussion}

The present study was the first to evaluate the influence of the self-assembling peptide SAP P11-4 on the shear bond strength of metal brackets. The study was conducted in accordance with the DIN standard 13990 for better comparison with other studies. Two test groups were included to evaluate whether there was an effect in the shear bond strength when the SAP P11-4 was applied directly before etching and insertion of the bracket or whether a remineralization period of $24 \mathrm{~h}$ would be rational prior to bracket bonding. No significant influence was identified on the bonding of a metal bracket to the enamel surface treated with SAP P11-4 either directly before or with a $24 \mathrm{~h}$ remineralization period in between.

For a clinically sufficient bond between tooth and metal bracket, values between 5.9 and 7.9 MPa were reported by Reynolds [45] and between 5 and 10 MPa by Diedrich [15]. The adhesive values found in our study were between 14.01 and $17 \mathrm{MPa}$. Hence, clinical sufficiency is therefore given.
Previous studies showed that other sealants also had no negative effect on the adhesive bond strength $[9,16,29,31$, 40]. A further clinical examination of the effectiveness of SAP11-4 as a bracket environment sealing is still pending.

Many studies focused on the influence of different pretreatment procedures on the shear bond strength such as sandblasting [14, 43] or application of different remineralization agents [36]. The sandblasting of enamel prior to bracket placement is commonly used to increase the shear bond strength and as a measure to reduce bracket failure rate. However, there are heterogeneous results about its effectiveness. In a study by Daratsianos et al. [14] sandblasting could not substitute acid etching and did not offer improved shear bond strength when used before acid etching. Reicheneder et al. [43] found increased shear bond strength values after pretreatment of enamel by sandblasting. In a study using casein phosphopeptide-amorphous calcium phosphate (CPP-ACP) and sodium fluoride mouthwash in different application protocols prior to bracket bonding, the evaluation of shear bond strength and ARI scores showed no significant difference between the study groups [36]. It was concluded that the use of CPP-ACP and fluoride can be considered a prophylactic application before bracket placement.

It should be considered that shear bond strength values measured in an in vitro study are normally higher than those measured intraorally during an orthodontic treatment. The difference between these shear bond strength values is on average $57 \%$ [41]. A recently published clinical study 
showed that enamel sealing with a light-cured filled material prior to adhesive bonding of brackets increased the rate of bond failure in the lower dental arch compared to enamel sealing after bracket bonding [27].

The presented results are in partial agreement with recent reports on the influence of SAP P11-4 on the resin bonding on carious dentine $[5,6]$. The authors could show improved bonding between demineralized dentine and composite after pretreatment with SAP P11-4 if a two-step bonding system was used. The increase in bond strength was presumably due to the increased mineral content of the carious dentine after application of SAP P11-4. As the present study used enamel with a markedly higher mineral content than demineralized dentin, such improvement was not to be expected and might also not be sought, as it might lead to issues when the brackets are removed from the enamel surface. The positive resistance of the SAP P11-4 conditioned enamel towards caries has been demonstrated in a recent in situ trial [24]. The in situ trial used a self-assembling peptide matrix (SAPM) gel, which is not suitable to be applied prior to bonding due to additional gel components that cannot be dried in a short time. Yet, various studies could show that SAP P11-4 leads to an inhibition of demineralization $[1,2,26]$.

The present study closed the knowledge gap with regards to the influence of SAP P11-4 on the bond strength of a metal bracket to the enamel surface. Further research is needed to show the surface characteristics of the enamel after application of SAP P11-4, e.g., the surfaces hardness or qualitative measurements using a scanning electron microscope [23]. Moreover, comparison of different preventive agents with the SAP P11-4 prior to bracket bonding should be performed to determine the optimum preventive care for teeth before fixed orthodontic treatment. As a next step clinical investigations are proposed to show the carious inhibitive effect of SAP P11-4 in the course of orthodontic treatment.

\section{Conclusion and clinical relevance}

The application of the caries protective SAP P11-4 before bonding did not significantly influence the bond strength of orthodontic brackets regardless of whether they were bonded immediately after application of SAP P11-4 or after a $24 \mathrm{~h}$ mineralization period. Thus, pretreatment of the enamel surface with SAP P11-4 can be considered before bracket bonding.

Funding The brackets were provided by Dentaurum (Ispringen, Germany). The Curodont Repair was provided by Credentis AG (Windisch, Switzerland).

Funding Open access funding enabled and organized by Projekt DEAL.

\section{Compliance with ethical guidelines}

Conflict of interest T. Knaup, H. Korbmacher-Steiner and A. Jablonski-Momeni declare that they have no competing interests.

Ethical standards This article does not report on any studies with human participants that were performed by any of the authors. The use of extracted teeth was approved by the Ethics Committee of the medical faculty of the Philipps University Marburg (Ref. No. 107/12).

Open Access This article is licensed under a Creative Commons Attribution 4.0 International License, which permits use, sharing, adaptation, distribution and reproduction in any medium or format, as long as you give appropriate credit to the original author(s) and the source, provide a link to the Creative Commons licence, and indicate if changes were made. The images or other third party material in this article are included in the article's Creative Commons licence, unless indicated otherwise in a credit line to the material. If material is not included in the article's Creative Commons licence and your intended use is not permitted by statutory regulation or exceeds the permitted use, you will need to obtain permission directly from the copyright holder. To view a copy of this licence, visit http://creativecommons.org/licenses/by/4. $0 \%$

\section{References}

1. Aggeli A, Fytas G, Vlassopoulos D, McLeish TC, Mawer PJ, Boden N (2001) Structure and dynamics of self-assembling beta-sheet peptide tapes by dynamic light scattering. Biomacromolecules 2:378-388

2. Alkilzy M, Tarabaih A, Santamaria RM, Splieth CH (2018) Selfassembling peptide p11-4 and fluoride for regenerating enamel. J Dent Res 97:148-154

3. Artun J, Bergland S (1984) Clinical trials with crystal growth conditioning as an alternative to acid-etch enamel pretreatment. Am J Orthod 85:333-340

4. Banks PA, Richmond S (1994) Enamel sealants: a clinical evaluation of their value during fixed appliance therapy. Eur J Orthod 16:19-25

5. Barbosa-Martins LF, de Sousa JP, de Castilho ARF, PuppinRontani J, Davies RPW, Puppin-Rontani RM (2018) Enhancing bond strength on demineralized dentin by pre-treatment with selective remineralising agents. J Mech Behav Biomed Mater $81: 214-221$

6. Barbosa-Martins LF, Sousa JP, Alves LA, Davies RPW, PuppinRontanti RM (2018) Biomimetic mineralizing agents recover the micro tensile bond strength of demineralized dentin. Materials 11:1733. https://doi.org/10.3390/ma11091733

7. Bechtold TE, Sobiegalla A, Markovic M, Berneburg M, Göz GR (2013) In vivo effectiveness of enamel sealants around orthodontic brackets. J Orofac Orthop 74:447-457

8. Benham AW, Campbell PM, Buschang PH (2009) Effectiveness of pit and fissure sealants in reducing white spot lesions during orthodontic treatment. A pilot study. Angle Orthod 79:338-345

9. Bishara SE, Oonsombat C, Soliman MM, Warren J (2005) Effects of using a new protective sealant on the bond strength of orthodontic brackets. Angle Orthod 75:243-246

10. Bröseler F, Tietmann C, Bommer C, Drechsel T, Heinzel-Gutenbrunner M, Jepsen S (2020) Randomised clinical trial investigating self-assembling peptide P11-4 in the treatment of early caries. Clin Oral Invest 24:123-132

11. Buren JL, Staley RN, Wefel J, Qian F (2008) Inhibition of enamel dem-ineralization by an enamel sealant, pro seal: an in-vitro study. Am J Orthod Dentofacial Orthop 133(Suppl 4):S88-S94 
12. Coordes SL, Jost-Brinkmann PG, Präger TM, Bartzela T, Visel D, Jäcker T, Müller-Hartwich R (2018) A comparison of different sealants preventing demineralization around brackets. J Orofac Orthop 79:49-56

13. Cosma LL, Şuhani RD, Mesaroş A, Badea ME (2019) Current treatment modalities of orthodontically induced white spot lesions and their outcome-a literature review. Med Pharm Rep 92:25-30

14. Daratsianos N, Schütz B, Reimann S, Weber A, Papageorgiou SN, Jäger A, Bourauel C (2019) The influence of enamel sandblasting on the shear bond strength and fractography of the bracket-adhesive-enamel complex tested in vitro by the DIN 13990:2017-04 standard. Clin Oral Investig 7:2975-2985

15. Diedrich P (1981) Die Verbundfestigkeit verschiedener orthodontischer Adhäsive zum konditionierten Schmelz und zur Bracketbasis. Fortschr Kieferorthop 42:305-320

16. El Bokle D, Munir H (2008) An in vitro study of the effect of Pro Seal varnish on the shear bond strength of orthodontic brackets. World J Orthod 9:141-146

17. Enaia M, Bock N, Ruf S (2011) White-spot lesions during multibracket appliance treatment: a challenge for clinical excellence. Am J Orthod Dentofacial Orthop 140:e17-e24

18. Fornell A-C, Sköld-Larsson K, Hallgren A, Bergstrand F, Twetman S (2002) Effect of a hydrophobic tooth coating on gingival health, mutans streptococci, and enamel demineralization in adolescents with fixed orthodontic appliances. Acta Odontol Scand 60:37-41

19. Hammad SM, Knösel M (2016) Efficacy of a new sealant to prevent white spot lesions during fixed orthodontic treatment: a 12-month, single-center, randomized controlled clinical trial. J Orofac Orthop 77:439-445

20. Höchli D, Hersberger-Zurfluh M, Papageorgiou SN, Eliades T (2017) Interventions for orthodontically induced white spot lesions: a systematic review and meta-analysis. Eur J Orthod 39:122-133

21. Hornby K, Evans M, Long M, Joiner A, Laucello M, Salvaderi A (2009) Enamel benefits of a new hydroxyapatite containing fluoride toothpaste. Int Dent J 59:325-331

22. Hu W, Featherstone JD (2005) Prevention of enamel demineralization: an in-vitro study using light-cured filled sealant. Am J Orthod Dentofacial Orthop 128:592-600

23. Jablonski-Momeni A, Heinzel-Gutenbrunner M (2014) Efficacy of the self-assembling peptide P11-4 in constructing a remineralization scaffold on artificially-induced enamel lesions on smooth surfaces. J Orofac Orthop 75:175-190

24. Jablonski-Momeni A, Korbmacher-Steiner H, Heinzel-Gutenbrunner M, Jablonski B, Jaquet W, Bottenberg P (2019) Randomised in situ clinical trial investigating self-assembling peptide matrix P11-4 in the prevention of artificial caries lesions. Sci Rep 9:269. https:// doi.org/10.1038/s41598-018-36536-4

25. Kind L, Stevanovic S, Wuttig S, Wimberger S, Hofer J, Müller B, Pieles U (2017) Biomimetic remineralization of carious lesions by self-assembling peptide. J Dent 96:790-797

26. Kirkham J, Firth A, Vernals D, Boden N, Robinson C, Shore RC, Brookes SJ, Aggeli A (2007) Self-assembling peptide scaffolds promote enamel remineralization. J Dent Res 86:426-430

27. Kirschneck C, Rohn C, Proff P, Reicheneder C (2019) Influence of enamel sealing with a light-cured filled sealant before bracket bonding on the bond failure rate during fixed orthodontic therapy. J Orofac Orthop 80:136-143

28. Lopatiene K, Borisovaite M, Lapenaite E (2016) Prevention andtreatment of white spot lesions during andafter treatment with fixedorthodontic appliances: a systematic literature review. J Oral Maxillofac Res 7:e1. https://doi.org/10.5037/jomr.2016.7201

29. Lowder PD, Foley T, Banting DW (2008) Bond strength of 4 orthodontic adhesives used with a caries-protective resin sealant. Am J Orthod Dentofacial Orthop 134:291-295
30. Machiulskiene V, Campus G, Carvalho JC, Dige I, Ekstrand KR, Jablonski-Momeni A et al (2019) Terminology of dental caries and dental caries management: consensus report of a workshop organized by ORCA and cariology research group of IADR (review). Caries Res 7:1-8

31. Mahajan V (2013) Effect of light-cured filled sealant on the shear bond strength of metal, ceramic and titanium brackets bonded with resin-modified glass ionomer cement. Indian J Dent Res 24:745-749

32. Migliorati M, Isaia L, Cassaro A, Rivetti A, Silvestrini-Biavati F, Gastaldo L et al (2014) Efficacy of professional hygiene and prophylaxis on preventing plaque increase in orthodontic patients with multibracket appliances: a systematic review. Eur J Orthod 37:297-307

33. Mohammed H, Rizk MZ, Wafaie K, Ulhaq A, Almuzian M (2019) Reminders improve oral hygiene and adherence to appointments in orthodontic patients: a systematic review and meta-analysis. Eur J Orthod 41:204-213

34. Montasser MA, Drummond JL, Evans CA (2008) Rebonding of orthodontic brackets. Part I, a laboratory and clinical study. Angle Orthod 78:531-536

35. Munjal D, Garg S, Dhindsa A, Sidhu GK, Sethi HS (2016) Assessment of white spot lesions and in-vivo evaluation of the effect of CPP-ACP on white spot lesions in permanent molars of children. J Clin Diagn Res 10:ZC149-ZC154. https://doi.org/10.7860/JCDR/ 2016/19458.7896

36. Naseh R, Fallahzadeh F, Atai M, Mortezai O, Setayeshrad R (2017) Casein phosphopeptide-amorphous calcium phosphate effects on brackets shear bond strength and enamel damage. J Clin Exp Dent 9:e1002-e1007. https://doi.org/10.4317/jced.54017

37. O'Reilly MT, De Jesús VJ, Hatch JP (2013) Effectiveness of a sealant compared with no sealant in preventing enamel demineralization in patients with fixed orthodontic appliances: a prospective clinical trial. Am J Orthod Dentofacial Orthop 143:837-844

38. Ogaard B, Rølla G, Arends J (1988) Orthodontic appliances and enamel demineralization. Part 1. Lesion development. Am J Orthod Dentofacial Orthop 94:68-73

39. Papageorgiou SN, Dimitraki D, Kotsanos N, Bekes K, van Waes H (2017) Performance of pit and fissure sealants according to tooth characteristics: a systematic review and meta-analysis. J Dent 66:8-17

40. Paschos E, Okuka S, Ilie N, Huth KC, Hickel R, Rudzki-Janson I (2006) Investigation of shear-peel bond strength of orthodontic brackets on enamel after using Pro Seal. J Orofac Orthop 67:196-206

41. Pickett KL, Sadowsky PL, Jacobson A, Lacefield W (2001) Orthodontic in vivo bond strength: comparison with in vitro results. Angle Orthod 71:141-148

42. Pitts NB, Zero DT, Marsh PD, Ekstrand K, Weintraub JA, RamosGomez F et al (2017) Dental caries. Nat Rev Dis Primers 3:17030. https://doi.org/10.1038/nrdp.2017.30

43. Reicheneder C, Hofrichter B, Faltermeier A, Proff P, Lippold C, Kirschneck C (2014) Shear bond strength of different retainer wires and bonding adhesives in consideration of the pretreatment process. Head Face Med 10:51. https://doi.org/10.1186/1746-160X-10-51

44. Ren Y, Jongsma MA, Mei L, van der Mei HC, Busscher HJ (2014) Orthodontic treatment with fixed appliances and biofilm formation - a potential public health threat? Clin Oral Investig 18:1711-1718

45. Reynolds IR (1975) A review of direct orthodontic bonding. Br J Orthod 2:171-178

46. Sonesson M, Bergstrand F, Gizani S, Twetman S (2017) Management of post-orthodontic white spot lesions: an updated systematic review. Eur J Orthod 39:116-121

47. Sundararaj D, Venkatachalapathy S, Tandon A, Pereira A (2015) Critical evaluation of incidence and prevalence of white spot lesions 
during fixed orthodontic appliance treatment: a meta-analysis. J Int Soc Prev Community Dent 5:433-439

48. Tasios T, Papageorgiou SN, Papadopoulos MA, Tsapas A, Haidich AB (2019) Prevention of orthodontic enamel demineralization: a systematic review with meta-analyses. Orthod Craniofac 22:225-235

49. Tran P, Hamood A, Mosley T, Gray T, Jarvis C, Webster D, Amaechi B, Enos T, Reid T (2013) Organo-selenium-containing dental sealant inhibits bacterial biofilm. J Dent Res 92:461-466

50. Wenderoth CJ, Weinstein M, Borislow AJ (1999) Effectiveness of a fluoride-releasing sealant in reducing decalcification during orthodontic treatment. Am J Orthod Dentofacial Orthop 116:629-634

51. Wright JT, Crall JJ, Fontana M, Gillette EJ, Nový BB, Dhar V et al (2016) Evidence-based clinical practice guideline for the use of pit-and-fissure sealants: a report of the American dental association and the American academy of pediatric dentistry. J Am Dent Assoc 147:672-682.e12. https://doi.org/10.1016/j.adaj.2016.06.001 